\title{
Role of Bambuterol in the Management of Bronchial Asthma
}

\author{
Gurumit Singh, Sonal Kesar, Ambika Sambyal, Sunil Grover \\ Department of TB and Respiratory Diseases, Sri Guru Ram Das Institute of Medical Sciences and Research, Amritsar, Punjab, India
}

\section{Abstract}

Background: Asthma is a long-term inflammatory disorder of the airways characterized by wheezing, dyspnea, and cough. For the last few decades, inhalational devices have been used in the management of the disease, but compliance remains the problem. Higher doses of oral medications used with prominent side effects precluded the use of oral beta-agonist bronchodilators, and the search for an ideal beta-adrenergic bronchodilator continues. This study was conducted for evaluation of the role of oral bambuterol in the management of bronchial asthma. Aims and Objectives: Our study aimed to evaluate the potency and effectiveness of oral bambuterol in the management of the disease in fifty patients followed up over 2 weeks with objective assessment of symptom scores and changes in the frequency of rescue bronchodilator after 2 weeks of treatment. Side effects, if any, were documented for all patients. Methods: The study was conducted on fifty patients with chronic bronchial asthma. They were given $10 \mathrm{mg}$ of bambuterol once daily orally for 14 days. Pulmonary function tests were performed at days 1,7 , and 14. Forced vital capacity (FVC), forced expiratory volume in $1 \mathrm{~s}\left(\mathrm{FEV}_{1}\right)$, and peak expiratory flow rate (PEFR) were measured. Patients were assessed for symptom score and side effects at days 1, 7, and 14. Results: After completion of the study, significant improvement in the symptom score, FVC, FEV ${ }_{1}$, and PEFR was obtained with minimal side effects. Conclusion: Bambuterol 10 mg oral tablet once a day provides significant improvement in pulmonary function tests and effectively reduces asthmatic symptoms with minimal side effects.

Keywords: Asthma, bambuterol, pulmonary function tests, symptom score

\section{INTRODUCTION}

Asthma is a disorder caused by airway hyperresponsiveness to various allergens. It involves interaction between bronchial hyperreactivity and airflow obstruction. This interaction varies among and within patients over time. ${ }^{[1]}$ There occurs inflammation of the airways which affects both the airway caliber and airflow, causing bronchospasm. ${ }^{[2]}$ Due to notable increase in the disease incidence, many new developments have been done to enhance the knowledge of pathophysiology of this disease, which results in episodic exacerbation of airway dysfunction, increased secretions, cough, and other symptoms. ${ }^{[3]}$ The pharmacotherapy of asthma helps to control both inflammation and spasm of bronchi. Corticosteroids and $\beta 2$-agonists are presently being used for the treatment, via inhalational route. Conventional $\beta 2$-adrenergic agonists act for shorter duration. The effect of newer bronchodilators is not more than $12 \mathrm{~h} .{ }^{[4,5]}$ Bambuterol is a long-acting $\beta$-adrenoceptor agonist having longer duration of action. It is used in the treatment of asthma. It stimulates through $\beta 2$-adrenergic receptors of intracellular adenylate cyclase (an enzyme which converts adenosine triphosphate into cyclic adenosine

\begin{tabular}{|l|l|}
\hline \multicolumn{2}{|c|}{ Access this article online } \\
\hline Quick Response Code: & Website: \\
& www.ijrconline.org \\
\cline { 2 - 2 } & \\
\hline
\end{tabular}

monophosphate [AMP]). Cyclic AMP promotes relaxation of smooth muscles of bronchus and inhibits release of mediators from primed mast cells. ${ }^{[6,7]}$ It is an inactive prodrug of terbutaline, which is an agonist of $\beta 2$-receptor. It undergoes oxidation and hydrolysis, mediated via butyrylcholinesterase, and is transformed into terbutaline. ${ }^{[8,9]}$ Bambuterol reversibly inhibits plasma cholinesterase in a dose-dependent manner, so the metabolism of its prodrug occurs in a slow and controlled fashion throughout the entire $24 \mathrm{~h} \cdot{ }^{[10,11]}$ Therefore, it works as an endogenous reservoir of terbutaline, allowing it to be used once daily. ${ }^{[12,13]}$

Thus, the clinical efficacy of once-daily bambuterol is almost equivalent to twice-daily sustained-release terbutaline. ${ }^{[14]}$ The pharmacokinetics of bambuterol and terbutaline in healthy controls was studied by Nyberg et al. $;^{[15]}$ the total clearance of bambuterol administered intravenously was $1.251 \mathrm{~min}^{-1}, 10 \%$

\section{Address for correspondence: Dr. Sunil Grover, 27 C, Yaseen Road, Near Lal Hospital, Amritsar, Punjab, India. E-mail: drsunilgrover332@gmail.com}

This is an open access journal, and articles are distributed under the terms of the Creative Commons Attribution-NonCommercial-ShareAlike 4.0 License, which allows others to remix, tweak, and build upon the work non-commercially, as long as appropriate credit is given and the new creations are licensed under the identical terms.

For reprints contact: reprints@medknow.com

How to cite this article: Singh G, Kesar S, Sambyal A, Grover S. Role of bambuterol in the management of bronchial asthma. Indian J Respir Care 2019;8:27-30. 
of which was of renal origin. After oral intake of bambuterol, terbutaline was released slowly for a longer duration which was confirmed by the flat profile of the plasma concentration versus time profile of terbutaline which was rather flat after the oral administration of bambuterol, thus favoring its once-daily administration.

Bambuterol has less side effects and similar clinical efficacy to other oral bronchodilators. ${ }^{[16]}$ The low frequency of side effects is explained by the smooth and sustained plasma levels of terbutaline released at a steady state. ${ }^{[17]}$ Other side effects include headache, tonic muscle cramps, and palpitations. These effects are dose dependent and majority of these reverse spontaneously within the first 1-2 weeks as found by Persson et al. ${ }^{[18]}$

\section{Aims and objectives}

1. To study the efficacy of oral bambuterol in the management of bronchial asthma

2. To study the improvement in symptom scores and any side effects after 2 weeks of therapy

3. To study the frequency of rescue bronchodilator used after 2 weeks of treatment.

\section{Methods}

This study was conducted on fifty patients suffering from chronic asthma attending the outpatient department of Department of TB and Respiratory Diseases, Sri Guru Ram Das Institute of Medical Sciences and Research, Amritsar, Punjab, India. The study comprised of both male and female patients with age ranging from 18 to 60 years. Patients having acute severe asthma were excluded from the study. Apart from a history of episodic breathlessness, cough, wheezing, and expectoration, a history of atopy or other allergy was also documented.

Inclusion criteria comprised of patients having reversible airway obstruction, i.e., $>12 \%$ reversibility and $200 \mathrm{ml}$ of forced expiratory volume in $1 \mathrm{~s}\left(\mathrm{FEV}_{1}\right)$ after 2 puffs of salbutamol inhaler $(100 \mu \mathrm{g} / \mathrm{puff})$ in the absence of any chest infection.

Exclusion criteria comprised of irreversible airway obstruction, chronic bronchitis, cor pulmonale, ischemic heart disease, impaired hepatic and renal functions, tuberculosis, and pregnant and lactating women.

Selected patients were given a single dose of oral bambuterol $10 \mathrm{mg}$ at evening time for 14 days with salbutamol inhaler as rescue inhaler. All the other bronchodilators were discontinued at least $48 \mathrm{~h}$ prior to the start of oral bambuterol, but those receiving oral steroids were allowed to continue.

Pulmonary function tests were done in each case at the start of therapy, i.e., day 1 and then at days 7 and 14. Upon performing spirometry, $\mathrm{FEV}_{1}$, forced vital capacity (FVC), and peak expiratory flow rate (PEFR) were documented.

The percentage reversibility in $\mathrm{FEV}_{1}$ was calculated by repeating the $\mathrm{FEV}_{1}, 15 \mathrm{~min}$ after two puffs of salbutamol (100 $\left.\mu \mathrm{g} / \mathrm{puff}\right)$.
These tests were done using a computerized spirometer (Ndd Medical Technologies) which also gave the predicted values of $\mathrm{FEV}_{1}, \mathrm{FVC}$, and PEFR as well as percentage of these values of each patient scaled to patient's height, weight, age, gender, and environmental temperature. The predicted values were based on European Respiratory Society/European Society of Cardiology for adult patients, i.e., $>17$ years. The patients were asked to follow up at days 7 and 14. Any side effects of oral bambuterol such as headache, tremor, palpitation, or tachycardia were documented.

Symptom scores at the start of therapy and at days 7 and 14 were noted to assess the subjective improvement.

The asthmatic symptoms were graded as follows:

- $\quad$ 0: No symptoms

- 1: Mild symptoms (i.e., patient is able to do his/her routine work despite the presence of symptoms without any difficulty, expiratory wheeze, decreased air entry at bases, and $\mathrm{SpO}_{2} 90 \%-93 \%$ )

- 2: Moderate symptoms (i.e., patient is able to do his/ her routine work but with some difficulty and sleep is disturbed due to these symptoms, suprasternal indrawing, scalene retractions, both inspiratory and expiratory wheeze, widespread decrease in air entry, and $\mathrm{SpO}_{2}<90 \%$ )

- 3: Severe symptoms (i.e., patient is unable to do work and sleep is disturbed, audible without stethoscope/silent chest with minimal air entry and absent/minimal air entry).

\section{Statistical analysis}

Paired Student's $t$-test was used to interpret the data. $P<0.05$ was considered statistically significant and $P<0.001$ as highly significant. Mean and standard deviation were calculated wherever required.

\section{RESULTS}

In this study, bambuterol, a prodrug of $\beta 2$ agonist terbutaline, was evaluated in the management of asthma. It was found that there were $28(56 \%)$ males and $22(44 \%)$ females. Majority of the cases were seen in the age group of $18-25$ years $(36 \%)$ [Table 1$]$.

Twenty-six patients (52\%) had a history of atopy and nasal allergy. Out of these, 10 were males and 16 were females [Table 2].

Family history of asthma was observed in $20(40 \%)$ cases [Table 3].

There was a significant increase in mean percentage $\mathrm{FEV}_{1}$ values at day 7 and day 14 from the basal percentage values by $20 \%$ and $33 \%$, respectively [Table 4 ].

A significant improvement in mean percentage value of FVC by $16 \%$ and $28 \%$ was noticed at days 7 and 14 , respectively [Table 5].

Similarly, there was also significant increase in mean percentage PEFR from basal percentage value by $13 \%$ and $22 \%$ by days 7 and 14 , respectively [Table 6]. 
Singh, et al.: Role of bambuterol in the management of bronchial asthma

The symptom score decreased from $7.36 \pm 1.80$ at day 1 to $3.80 \pm 1.87$ at day 7 and $1.08 \pm 1.07$ at day 14 [Table 7].

Drug was well tolerated by most of the patients. Mild headache was reported in 12 patients and tremors in four patients [Table 8].

The mean frequency of rescue bronchodilator decreased from $3.06 \mathrm{puffs} /$ day for each patient at day 7 to $1.1 \mathrm{puff} /$ day for each patient at day 14 [Table 9].

\section{Discussion}

Bambuterol, the prodrug of terbutaline, improves airflow status over $24 \mathrm{~h}$ when administered once daily in the evening. Bambuterol when given in the evening resulted in a statistically significant increase in $\mathrm{FEV}_{1}, \mathrm{FVC}$, and PEFR. The frequency of asthma symptoms declined at the end of this study. The main objectives of asthma treatment are to control symptoms and maintain near-normal pulmonary function and normal physical activity. ${ }^{[17,19]}$

In this study, there was a significant increase in $\mathrm{FEV}_{1}, \mathrm{FVC}$, and PEFR values on days 7 and 14 after treatment with oral

\begin{tabular}{|c|c|c|c|}
\hline Age groups (years) & Male & Female & Total (\%) \\
\hline$<25$ & 10 & 8 & $18(36)$ \\
\hline $26-35$ & 2 & 6 & $8(16)$ \\
\hline $36-45$ & 8 & 8 & $16(32)$ \\
\hline $46-55$ & 4 & & $4(8)$ \\
\hline $56-60$ & 4 & & $4(8)$ \\
\hline Total (\%) & $28(56)$ & $22(44)$ & $50(100)$ \\
\hline
\end{tabular}

Table 2: History of atopy and allergy

\begin{tabular}{lc}
\hline Sex & Number of patients (\%) \\
\hline Males & $10(20)$ \\
Females & $16(32)$ \\
Total & $26(52)$ \\
\hline
\end{tabular}

Table 3: Family history of bronchial asthma

\begin{tabular}{lc}
\hline Sex & Number of patients (\%) \\
\hline Males & $12(24)$ \\
Females & $8(16)$ \\
Total & $20(40)$ \\
\hline
\end{tabular}

Table 4: Forced expiratory volume in $1 \mathrm{~s}(\mathrm{I} / \mathrm{s})$

\begin{tabular}{lcccc}
\hline & Mean & SD & $\boldsymbol{t}$ & $\boldsymbol{P}$ \\
\hline Predicted & 2.50 & 0.64 & & \\
Basal & 1.08 & 0.36 & & \\
Postsalbutamol & 1.50 & 0.58 & & \\
Day 7 & 1.58 & 0.54 & 3.85 & $<0.001$ \\
Day 14 & 1.91 & 0.61 & 5.86 & $<0.001$ \\
\hline
\end{tabular}

SD: Standard deviation bambuterol. Furthermore, the mean symptom score decreased to $3.80 \pm 1.87$ on day 7 and to $1.80 \pm 1.07$ on day 14 . Persson et al. ${ }^{[18]}$ also reported that $10 \mathrm{mg}$ bambuterol when given orally acts effectively for $24 \mathrm{~h}$. This is depicted as an increase in mean daily morning and evening PEFR (11 L/min, adjusted means) throughout the study, as compared with placebo. Persson et al.$^{[18]}$ found that mean baseline $\mathrm{FEV}_{1}$ and $\mathrm{FEV}_{1} \%$ of predicted values were $2.05 \mathrm{~L}$ and $62 \%$, respectively. In this study, it was found that the total number of rescue bronchodilator puffs was also reduced. These findings were consistent with the findings of Petrie et al. ${ }^{[20]}$ who reported a $16 \%$ increase in mean PEFR on awaking and $10 \%$ improvement in evening PEFR measured $24 \mathrm{~h}$ after bambuterol $20 \mathrm{mg}$ intake.

\begin{tabular}{|c|c|c|c|c|}
\hline & Mean & SD & $t$ & $P$ \\
\hline Predicted & 3.02 & 0.68 & & \\
\hline Basal & 1.23 & 0.54 & & \\
\hline Postsalbutamol & 1.61 & 0.59 & & \\
\hline Day 7 & 1.72 & 0.61 & 3.00 & $<0.001$ \\
\hline Day 14 & 2.07 & 0.68 & 4.97 & $<0.001$ \\
\hline
\end{tabular}

SD: Standard deviation

\begin{tabular}{|c|c|c|c|c|}
\hline & Mean & SD & $t$ & $P$ \\
\hline Predicted & 459.12 & 88.39 & & \\
\hline Basal & 132.24 & 75.13 & & \\
\hline Postsalbutamol & 175.20 & 70.95 & & \\
\hline Day 7 & 195.60 & 86.79 & 2.77 & $<0.05$ \\
\hline Day 14 & 235.68 & 80.43 & 4.74 & $<0.05$ \\
\hline
\end{tabular}

SD: Standard deviation

Table 7: Symptom score

\begin{tabular}{lcc}
\hline & Mean & SD \\
\hline Day 1 & 7.36 & 1.80 \\
Day 7 & 3.80 & 1.87 \\
Day 14 & 1.08 & 1.07 \\
\hline
\end{tabular}

SD: Standard deviation

Table 8: Side effects

\begin{tabular}{lc}
\hline Side effect & Number of patients (\%) \\
\hline Mild headache & $12(24)$ \\
Tremor & $4(8)$ \\
Restlessness and nausea & $2(4)$ \\
\hline
\end{tabular}

\section{Table 9: Rescue bronchodilators}

\begin{tabular}{lcc}
\hline & Number of puffs & Mean puffs \\
\hline $1^{\text {st }}$ week & 1074 & 21.48 \\
$2^{\text {nd }}$ week & 388 & 7.76 \\
\hline
\end{tabular}

Frequency of puffs after 1 week: 3.06 puffs/day, Frequency of puffs after 2 weeks: $1.1 \mathrm{puffs} /$ day 
Singh, et al.: Role of bambuterol in the management of bronchial asthma

In our study, the maximum cases of bronchial asthma were seen in the age group of 18-25 years (36\%). Wig et al. ${ }^{[21]}$ also found higher incidence of bronchial asthma in younger age group.

Very few adverse effects of bambuterol were reported in the study and no patients withdrew because of them. The frequent complaints were headache, mild tremors, and restlessness. Headache was noticed in $24 \%$, tremors in $8 \%$, and restlessness and nausea in $4 \%$ of patients each. These results were similar to those reported by Persson et al. ${ }^{[18]}$

\section{ConcLusion}

Bambuterol $10 \mathrm{mg}$ oral tablet once a day provides significant improvement in pulmonary function tests and effectively reduces asthmatic symptoms with minimal side effects. Even after three decades of emphasis on inhalation devices, a considerable population has been observed to not accept them and compliance problems persist. Bambuterol shows a promising role in such asthmatic patients who are noncompliant with inhalation devices or techniques but are willing to adhere to oral therapy. It is in such group of patients that reintroduction of bambuterol fills the missing gap in the management in terms of both results and compliance. Thus, it appears to be ideal for the treatment of asthma.

\section{Financial support and sponsorship}

Nil.

\section{Conflicts of interest}

There are no conflicts of interest.

\section{RefERENCES}

1. Busse WW, Lemanske RF Jr. Asthma. N Engl J Med 2001;344:350-62.

2. Cohn L, Elias JA, Chupp GL. Asthma: Mechanisms of disease persistence and progression. Annu Rev Immunol 2004;22:789-815.

3. Maddox L, Schwartz DA. The pathophysiology of asthma. Annu Rev Med 2002;53:477-98.

4. Ullman A, Svedmyr N. Salmeterol, a new long acting inhaled beta 2 adrenoceptor agonist: Comparison with salbutamol in adult asthmatic patients. Thorax 1988;43:674-8.

5. Becker AB, Simons FE. Formoterol, a new long-acting selective beta 2-adrenergic receptor agonist: Double-blind comparison with salbutamol and placebo in children with asthma. J Allergy Clin Immunol 1989;84:891-5.

6. Svensson LA. Mechanism of action of bambuterol: A beta-agonist prodrug with sustained lung affinity. Agents Actions Suppl 1991;34:71-8.

7. Chou YL, Wu CC, Wang HW. Effects of bambuterol and terbutaline on isolated rat's tracheal smooth muscle. Eur Arch Otorhinolaryngol 2010;267:1305-11.

8. Krawiec ME, Jarjour NJ. Leukotriene receptor antagonists. Semin Respir Crit Care Med 2002;23:399-410.

9. Sitar DS. Clinical pharmacokinetics of bambuterol. Clin Pharmacokinet 1996;31:246-56.

10. Tunek A, Svensson LA. Bambuterol, a carbamate ester prodrug of terbutaline, as inhibitor of cholinesterases in human blood. Drug Metab Dispos 1988;16:759-64.

11. Tunek A, Levin E, Svensson LA. Hydrolysis of 3H-bambuterol, a carbamate prodrug of terbutaline, in blood from humans and laboratory animals in vitro. Biochem Pharmacol 1988;37:3867-76.

12. Persson G, Pahlm O. Efficacy and safety of bambuterol once daily in comparison with terbutaline tid. Clin Exp Allergy 1990;20 suppl 1:35.

13. Van den Berg W, Alanko K, Sahlstrom K, Jarvinen M, Mikkola E, Jansson $\mathrm{C}$, et al. Bambuterol once every evening in combination with terbutaline t.i.d. in asthmatic patients. Clin Exp Allergy 1990;20 suppl 1:35.

14. Fugleholm AM, Ibsen TB, Laxmyr L, Svendsen UG. Therapeutic equivalence between bambuterol, $10 \mathrm{mg}$ once daily, and terbutaline controlled release, $5 \mathrm{mg}$ twice daily, in mild to moderate asthma. Eur Respir J 1993;6:1474-8.

15. Nyberg L, Rosenborg J, Weibull E, Jönsson S, Kennedy BM, Nilsson M, et al. Pharmacokinetics of bambuterol in healthy subjects. Br J Clin Pharmacol 1998;45:471-8.

16. Larsén K, Schmekel B. Tremor in healthy volunteers after bambuterol and terbutaline CR-tablets. Eur J Clin Pharmacol 1993;45:303-5.

17. Global Initiative for Asthma. Global Strategy for Asthma Management and Prevention: NHLBI/WHO Workshop Report. Publication No. 02-3659. Bethesda: National Institutes of Health, National Heart, Lung and Blood Institute; 2002.

18. Persson G, Baas A, Knight A, Larsen B, Olsson H. One month treatment with the once daily oral beta 2-agonist bambuterol in asthmatic patients. Eur Respir J 1995;8:34-9.

19. Boskabady MH, Fasihfar M, Maemoori GA. Correlation between symptom score, wheeze, reversibility of pulmonary function tests and treatment response in asthma. Iran J Allergy Asthma Immunol 2003;2:61-7.

20. Petrie GR, Chookang JY, Hassan WU, Morrison JF, O'Reilly JF, Pearson SB, et al. Bambuterol: Effective in nocturnal asthma. Respir Med 1993;87:581-5.

21. Wig KL, Guleria JS, Bhasin RC, Holmes E, Vasudeva YL, Singh H. Certain clinical and epidemiological patterns of chronic obstructive lung disease as seen in Northern India. Indian J Chest Dis 1964;6:183-94 